\title{
DISCUTINDO A RELAÇÃO GÊNERO/TRÂNSITO NA ESCOLA
}

\author{
Marilsa Aparecida Alberto Assis Souza ${ }^{1}$
}

Eixo temático: Políticas de educação, direitos sociais e cidadania.

\section{INTRODUÇÃO}

Este trabalho surgiu em decorrência do Curso Gênero e Diversidade na Escola - Formação de Professoras/es em Gênero, Sexualidade, Orientação Sexual e Relações Étnico-Raciais, que é fruto de uma parceria da Secretaria de Educação Continuada, Alfabetização e Diversidade (SECAD/MEC) com a Secretaria Especial de Políticas para as Mulheres e a Secretaria Especial de Políticas de Promoção da Igualdade Racial, ofertado pela Universidade Federal de Minas Gerais no âmbito da Universidade Aberta do Brasil. O curso, que teve como objetivo principal promover a igualdade e o enfrentamento do preconceito e de todas as formas de discriminação no espaço escolar, propôs aos participantes que entregassem, por ocasião de seu término, uma proposta de intervenção a ser trabalhada nas escolas sobre uma das temáticas estudadas. Para tanto, cada cursista deveria analisar o espaço escolar para perceber qual (ou quais) destas temáticas estaria necessitando de uma intervenção mais imediata em seu ambiente de trabalho.

Trabalhando como educadora de trânsito e desenvolvendo projetos de educação no trânsito em escolas de Ensino Fundamental e Médio, considerei que dentre as temáticas estudadas no curso o preconceito referente à questão do gênero era o mais visível no contexto do trânsito, o que pode ser percebido por meio das frases "Mulher no volante, perigo constante!" ou "Tinha que ser mulher!".

Sendo assim, este trabalho foi dividido em três partes: uma pesquisa feita com mulheres condutoras de veículos da cidade com o objetivo de saber se, de fato, elas têm sido tratadas de forma preconceituosa no trânsito e como se sentem diante do preconceito; uma pesquisa aplicada a adolescentes com o intuito de perceber se eles reproduzem comportamentos preconceituosos e discriminatórios aprendidos nas relações sociais e a proposta de intervenção a ser trabalhada nas escolas, tendo em vista que o ambiente escolar, por ser espaço eminentemente educativo, pode

\footnotetext{
${ }^{1}$ Universidade Federal de Minas Gerais - PMU
} 
colaborar no processo de desconstrução de mitos e preconceitos que permeiam as relações de gênero.

\section{MULHER NO VOLANTE, PERIGO CONSTANTE?}

A pesquisa direcionada às mulheres condutoras da cidade de Uberaba/MG contou a participação de 89 pessoas que responderam aos questionários apresentados. A primeira parte da pesquisa visava conhecer o perfil destas mulheres e a segunda parte tinha como intuito investigar se as mulheres, ainda hoje, sofrem preconceito e discriminação no trânsito; como reagem quando são discriminadas e qual a percepção que têm em relação à questão gênero e trânsito. Questionadas sobre a frequência com que já sofreram algum tipo de preconceito e/ou discriminação; foram alvo de alguma brincadeira; ouviram algum comentário pejorativo no trânsito pelo fato de serem mulheres, 32\% informaram nunca ter sofrido este tipo de discriminação enquanto $68 \%$ das mulheres afirmaram já ter passado por situações de preconceito.

A seguir foi solicitado que relatassem uma situação vivenciada que exemplificasse esta situação de preconceito. Muitas mulheres sentem o preconceito por meio de expressões como: "Tinha que ser mulher!"; "Vá pilotar fogão!”; "Mulher no volante, perigo constante!"; "Acelera tartaruga!", etc. Outras já se sentiram discriminadas quando, em situação de acidente, foram pré-julgadas como responsáveis pela situação, quando na verdade não foram elas as responsáveis pelo acidente. O preconceito também é percebido por meio de piadas e brincadeiras maldosas, inclusive do marido, filhos, pai e/ou amigos, além dos gestos de impaciência, olhares, risadas e até xingamentos.

$\mathrm{Na}$ pergunta seguinte foi solicitado que as mulheres relatassem como se sentem quando sofrem preconceito no trânsito. As respostas foram diversificadas, expressando diferentes sentimentos e emoções: "Acho desagradável"; "Fico chateada"; "Sinto-me inferiorizada"; "Fico irritada"; "Fico com raiva"; "Sinto-me

péssima"; "Sinto-me impotente"; "Sinto-me totalmente exposta"; "Sinto-me diminuída"; "Não gosto"; "Fico indignada"; "Sinto-me acuada"; "Sinto-me agredida e humilhada"; "Fico constrangida"; "Sinto-me injustiçada"; "Revoltada"; "Triste"; "Nervosa"; "Reprimida". Algumas mulheres, inclusive, manifestaram que sentem 
medo de dirigir por conta deste comportamento preconceituoso que vivenciam no trânsito.

Percebe-se, pelas respostas, que o preconceito é uma forma de violência psicológica. De acordo com Melo,

A violência psicológica inclui todas as condutas ou ações que tenham como propósito ofender, controlar e bloquear a autonomia de outro ser humano, seu comportamento, suas crenças e decisões. Pode ocorrer por meio de agressão verbal, humilhação, intimidação, desvalorização, ridicularização, indiferença, ameaça, isolamento, controle econômico ou qualquer outra conduta que interfira nesse direito básico de autodeterminação e desenvolvimento pessoal. (MELO, 2008)

As perguntas seguintes buscavam saber o que as mulheres pensam sobre a relação gênero e trânsito. $47 \%$ das participantes da pesquisa acreditam que as mulheres são melhores no trânsito que os homens e $47 \%$ acreditam que homens e mulheres são iguais. Apenas $6 \%$ acreditam que as mulheres são piores que os homens no volante.

A seguir foi pedido que justificassem a resposta dada à pergunta anterior. As participantes que responderam que as mulheres são melhores que os homens no volante disseram que elas são mais cuidadosas; mais cautelosas; mais atenciosas; mais prudentes; mais pacientes; mais observadoras; respeitam mais as leis; são mais tranqüilas; não se arriscam; são mais concentradas; são mais responsáveis; são menos afoitas; são mais educadas; são mais preventivas; têm mais receio.

Observa-se que foram elencadas diversas características consideradas mais expressivas nas pessoas do gênero feminino, tornando-as diferentes ao volante quando comparadas às pessoas do gênero masculino. Tais características mostram a forma como a mulher se vê na sociedade e ao mesmo tempo mostram o que dela é esperado nas relações sociais.

Neste ponto torna-se importante refletir se tais características são herdadas geneticamente ou se são fruto das aprendizagens sócio-culturais. Existe todo um aparato ideológico que, amparado por explicações científicas, atribui às questões hormonais ou à constituição do cérebro as diferenças de gênero: devido ao instinto materno as mulheres são dóceis, submissas, cautelosas, ao passo que os homens são arrojados e agressivos.

Esta forma de pensar desencadeia tratamentos diferentes, desde cedo, para meninos e meninas, na família e na escola, por seus pais, mães, 
professores/as e sociedade em geral. Existem determinados comportamentos que são esperados para meninos e outros para meninas. Espera-se que os meninos sejam indisciplinados, bagunceiros, desorganizados, contestadores e valentes ao passo que das meninas é esperado que sejam dóceis, frágeis, medrosas e obedientes. Não é de se estranhar, portanto, que tais comportamentos apresentem reflexos no contexto do trânsito. O menino que é ensinado a não ter medo de nada provavelmente não terá medo de desafiar a velocidade, colocando a própria vida em risco. À mulher, ao contrário, que é ensinada a ser submissa e obediente, caberá o medo de dirigir, a timidez no volante ou a obediência cega às normas.

Barreto, entretanto, afirma que:

O papel que a biologia desempenha na determinação de comportamentos sociais é fraco - a espécie humana é essencialmente dependente da socialização. Contudo, de acordo com o senso comum, as condutas de homens e mulheres originam-se de uma dimensão natural (os instintos) inscrita nos corpos com que cada indivíduo nasce. Acredita-se, com frequência, que existe um tipo de personalidade ou padrão de comportamento para cada um dos sexos. Na cultura ocidental, supõe-se que o masculino seja dotado de maior agressividade e o feminino de maior suavidade e delicadeza. (BARRETO, 2009, p. 45)

Da mesma forma Moreno sugere que a imagem que construímos acerca do outro e de nós mesmos é decorrente das relações construídas na sociedade: Esta imagem, nós não a fabricamos do nada, mas a construímos a partir dos modelos que a sociedade nos oferece. E é a sociedade e não a biologia ou os genes quem determina como devemos ser e nos comportar, quais são nossas possibilidades e nossos limites. (MORENO, 1999, p. 28).

Desta forma, acreditando que as diferenças entre os gêneros não estão inscritas nos corpos, mas são decorrentes das aprendizagens sócio-culturais construídas desde a infância, é possível desconstruí-las por meio da educação:

\footnotetext{
Vem daí a necessidade da educação. Se os seres humanos se comportassem unicamente a partir de seus impulsos biológicos, se as condutas consideradas masculinas e femininas fossem espontâneas, naturais e predeterminadas, não seria necessário educar tão cuidadosamente todos os aspectos diferenciais; bastaria deixar que a natureza atuasse por si mesma. (MORENO, 1999, p.28).
}

Moreno, portanto, enfatiza o papel da educação e consequentemente da escola neste processo de desnaturalização das diferenças por meio da reflexão, no cotidiano escolar, dos estereótipos construídos socialmente que reforçam não só a diferença entre os gêneros, mas a desigualdade. 
Continuando a pesquisa foi perguntando às mulheres se, diante de alguma situação inadequada no trânsito provocada por uma mulher, já tinham utilizado a expressão "Tinha que ser mulher" ou "Mulher no volante, perigo constante". $36 \%$ responderam que sim, e 57\% responderam que não. Embora a porcentagem de mulheres que já utilizou estas expressões seja menor, percebe-se que a própria mulher reforça o preconceito de gênero por meio da reprodução dos discursos veiculados na sociedade.

Silva apresenta outras expressões utilizadas na linguagem que reforçam a desigualdade entre os gênero, quase sempre inferiorizando o feminino:

Existem várias expressões gramaticais em nossa língua que aludem a uma
diferença de valores entre homem e mulher. Assim, "agir como homem"
significa agir com bravura, ser valente, corajoso. Mas, "agir como uma
mulher" é ser covarde, maricas, fraco, etc. "Bancar o homem" é bom, seja
para qualquer um dos sexos. Mas "bancar a mulherzinha" é insultante
quando dita para um homem. Existe até o termo "hombridade" (cujo
morfema lexical é homem) significando nobreza de caráter, dignidade. Mas
não existe o correspondente "mulheridade". (SILVA, 1988, p. 57)

Vale ressaltar que a linguagem, além de ser utilizada para inferiorizar a mulher, pode também invisibilizá-la quando o interlocutor emprega substantivos, adjetivos e artigos no gênero masculino mesmo querendo referir-se ao feminino, o que pode ser explicitado nas palavras de Pupo (2008):

A linguagem oral reflete essa discriminação sexista e reforça o modelo
lingüístico androcêntrico. Existem palavras para denominar o indivíduo do
sexo masculino e outras para o sexo feminino, mas quando por razões de
economia é preciso utilizar uma forma comum para se referir a indivíduos de
ambos os sexos, a opção é sempre pelo termo no masculino - o homem,
senhores pais, prezados alunos -; dessa forma, a identidade sexolinguística
feminina fica distorcida. A menina deve aprender sua identidade
sexolinguística para imediatamente renunciar a ela. O mesmo ocorre nos
estudos sobre educação que utilizam indistintamente termos aparentemente
neutros, masculinos ou femininos, desconsiderando a distinção de sexo das
(os) professoras (es), o que pode ser utilizado para reforço de estereótipos e
preconceitos de gênero.

Retomando a pesquisa, a mesma pergunta sobre a utilização das expressões "Mulher no volante, perigo constante!" e "Tinha que ser mulher!", foi direcionada a um grupo de adolescentes de ambos os sexos, de 13 a 17 anos. Dentre as mulheres do grupo, 51\% afirmaram que já utilizaram estas expressões, e dentre os homens, $68 \%$ também confirmaram sua utilização. Observa-se, portanto, a reprodução dos discursos veiculados nas relações sociais, sem maiores reflexões sobre seu real significado. Tal situação reporta ao conceito, explicitado por Bourdieu (1999), de violência simbólica, segundo o qual nas relações sociais em que o vínculo 
é de domínio/submissão, os dominados, inconsciente e involuntariamente, assimilam os valores e a visão do mundo dos dominantes e desse modo tornam-se cúmplices da ordem estabelecida sem perceberem que são as primeiras e principais vítimas dessa mesma ordem.

É importante refletir aqui que este processo de naturalização que desencadeia as desigualdades muitas vezes vai além do uso de determinadas expressões sexistas, mas se concretizam em comportamentos violentos contra a mulher.

Percebe-se, portanto, pelos dados apresentados na pesquisa, que o preconceito está presente no contexto do trânsito e, como toda forma de preconceito, precisa ser combatido para assegurar os direitos sociais e o exercício pleno da cidadan

\section{PROPOSTA DE INTERVENÇÃO “RELAÇÃO GÊNERO/TRÂNSITO: CONSTRUINDO A IGUALDADE POR MEIO DA DESCONSTRUÇÃO DE MITOS”.}

O trânsito é um espaço social onde é possível encontrar pessoas de diversas etnias, gêneros, idades, classes sociais, profissões, etc. Cada pessoa que circula por este espaço tem um objetivo próprio, que é chegar a um determinado lugar. Sendo assim, estão submetidas a regras comuns de circulação que devem ser cumpridas para que o interesse individual seja atingido.

Vasconcelos (1992) lembra, entretanto, que as relações no trânsito não se dão entre pessoas "iguais", pois a disputa pelo espaço tem uma base ideológica e política, visto que depende de como as pessoas se vêem na sociedade e de seu acesso real ao poder. Sendo assim, no contexto do trânsito as pessoas vivenciam situações implícitas de poder, de acordo com o pertencimento ou não pertencimento a determinado grupo social.

O ciclista, por exemplo, geralmente é inferiorizado em relação ao motociclista; o pedestre é inferiorizado em relação ao condutor e a mulher é inferiorizada em relação ao homem. Tal situação contraria o princípio da igualdade previsto na Constituição Federal e o Código de Trânsito Brasileiro que preconiza, em seu artigo 29, que os veículos de maior porte serão sempre responsáveis pela segurança dos menores, os motorizados pelos não motorizados e, juntos, pela incolumidade dos pedestres. 
A discriminação da mulher no trânsito reporta à distinção historicamente construída que submete a mulher ao espaço da casa, do lar, cumprindo seu papel reprodutor e destina o homem ao mundo público, a rua, cumprindo o papel de provedor. Embora a forma de apropriação do espaço pela mulher venha se modificando através dos tempos, o discurso social que rege as condutas de gênero continua propagando relações hegemônicas de poder, dizendo que "lugar de mulher é na cozinha, pilotando fogão". Este discurso é sustentado por uma ideologia que atribui as diferenças entre homens e mulheres a fatores unicamente genéticos, desconsiderando as aprendizagens sócio-culturais construídas desde a infância. Esta forma de pensar naturaliza as diferenças, aumentando o preconceito e a discriminação.

No contexto do trânsito, entretanto, vale ressaltar que o importante é que os condutores e as condutoras tenham qualificação e responsabilidades suficientes para não colocarem em risco a segurança das pessoas que circulam pelas vias, independente do sexo ao qual pertencem. Não se trata, portanto, de discutir quem é o/a melhor no trânsito visto que, não existe "a mulher", mas várias e diferentes mulheres que não são idênticas entre si, que podem ou não ser solidárias, cúmplices ou opositoras (Louro 2001). Além do mais, Vasconcelos (1992) lembra que diante das centenas de situações enfrentadas no trânsito, cada pessoa terá uma reação, que depende de uma série complexa de fatos ligados à cultura, ideologia, personalidade, mas também às condições do momento e da pessoa naquele dia exato.

Reconhecer esta diversidade e perceber que comportamentos preconceituosos podem ser modificados pela educação é um importante passo para a construção de uma sociedade mais justa e de um trânsito mais humano e consequentemente seguro.

Com base nesta fundamentação, a proposta de intervenção a ser trabalhada nas escolas, preferencialmente com alunos/as das séries finais do Ensino Fundamental e Ensino Médio pretende, por meio de atividades diversas como músicas, filmes, leituras, pesquisas, entrevistas, jogos, dinâmicas e outras, refletir sobre a forma com que as pessoas se relacionam no dia a dia do trânsito; analisar como as relações de gênero estão configuradas na sociedade, especialmente no contexto do trânsito; discutir as relações de poder que configuram as relações sociais entre homens e mulheres no decorrer da história; refletir sobre os mitos e 
estereótipos referentes à questão do gênero; perceber as distinções historicamente construídas da rua enquanto espaço público masculino e do lar enquanto espaço doméstico feminino e estimular o protagonismo juvenil por meio de atitudes que promovam o respeito à diversidade.

\section{CONSIDERAÇÕES FINAIS}

É importante lembrar que o trânsito é apenas um dos espaços sociais em que o preconceito de gênero se manifesta. Sendo assim, refletindo sobre as relações de gênero no trânsito emergirão outros temas importantes acerca do preconceito e da discriminação contra a mulher que estão presentes em todos os espaços da vida social brasileira, incluindo, portanto, a escola.

Acreditando, entretanto, que a história não é estática, a incorporação deste debate no ambiente escolar pretende ajudar na construção de uma sociedade menos desigual, onde os direitos sociais sejam garantidos e a cidadania concretizada. A construção de uma sociedade mais plural e democrática passa necessariamente pela desconstrução de mitos e estereótipos que insistem em justificar comportamentos preconceituosos e discriminatórios. Necessário se faz, portanto, que as regras de desigualdade até então internalizadas e naturalizadas socialmente sejam historicizadas, discutidas, problematizadas, trazidas para as rodas de conversa, explicitando as diferenças que insistem em manter a mulher em um patamar social inferior ao masculino.

\section{REFERÊNCIAS}

BARRETO, Andréia (org.). Gênero e Diversidade na Escola. Formação de Professoras/es em Gênero, Sexualidade, Orientação Sexual e Relações ÉtnicoRaciais. Brasília: SPM, 2009.

BOURDIEU, Pierre. A Dominação Masculina. Rio de Janeiro: Bertrand Brasil, 1999.

BRASIL. Código de Trânsito Brasileiro e Legislação Complementar em Vigor. Brasília: DENATRAN, 2008.

LOURO, Guaciara Lopes. Gênero, Sexualidade e Educação. Petrópolis: Vozes, 2001. 
MELO, Mônica de. Violência Psicológica contra a Mulher. Disponível em shttp://www.ibap.org/direitosdamulher/monicademelo/mm010.htm> Acesso: 23 out.2009.

MORENO, Montserrat. Como se ensina a ser menina: o sexismo na escola. Campinas: Moderna, 1999.

PUPO, Kátia. Questão de gênero na escola. Disponível em $\leq$ http://www.smec.salvador.ba.gov.br/site/documentos/espaco-virtual/espaco etica/WEBARTIGOS/questao\%20de\%20genero\%20na\%20escola.pdf> Acesso: 14 out 2009.

SILVA, Maria Escolástica Álvares da. Mulher: Substantivo Masculino. Campinas: UNICAMP, 1988.

VASCONCELOS, Eduardo Alcântara de. O que é Trânsito. São Paulo: Brasiliense, 1992

Recebido para publicação em: 20/12/2009

Aceito: 02/07/2010 